\title{
Dauricine inhibits insulin-like growth factor-I-induced hypoxia inducible factor 1a protein accumulation and vascular endothelial growth factor expression in human breast cancer cells
}

\author{
Xu-dong TANG ${ }^{1, *}$, Xin ZHOU ${ }^{1, *}$, Ke-yuan ZHOU ${ }^{2}$ \\ ${ }^{1}$ Clinical Genetic Diagnosis Center, Zhongnan Hospital, Wuhan University, Wuhan 430071, China; ${ }^{2}$ Department of Biochemistry and Molecular Biology, \\ Guangdong Medical College, Zhanjiang 524023, China
}

\begin{abstract}
Aim: To investigate the effects of dauricine (Dau) on insulin-like growth factor-I (IGF-I)-induced hypoxia inducible factor 1a (HIF-1a) and vascular endothelial growth factor (VEGF) expression in human breast cancer cells (MCF-7).

Methods: Serum-starved MCF-7 cells were pretreated for $1 \mathrm{~h}$ with different concentrations of Dau, followed by incubation with IGF-I for $6 \mathrm{~h}$. HIF-1a and VEGF protein expression levels were analyzed by Western blotting and ELISA, respectively. HIF-1a and VEGF mRNA levels were determined by real-time PCR. In vitro angiogenesis was observed via the human umbilical vein endothelial cell (HUVEC) tube formation assay. An in vitro invasion assay on HUVECs was performed.

Results: Dau significantly inhibited IGF-I-induced HIF-1a protein expression but had no effect on HIF-1a mRNA expression. However, Dau remarkably suppressed VEGF expression at both protein and mRNA levels in response to IGF-I. Mechanistically, Dau suppressed IGF-I-induced HIF-1a and VEGF protein expression mainly by blocking the activation of PI-3K/AKT/mTOR signaling pathway. In addition, Dau reduced IGF-I-induced HIF-1a protein accumulation by inhibiting its synthesis as well as by promoting its degradation. Functionally, Dau inhibited angiogenesis in vitro. Moreover, Dau had a direct effect on IGF-I-induced invasion of HUVECs.

Conclusion: Dau inhibits human breast cancer angiogenesis by suppressing HIF-1a protein accumulation and VEGF expression, which may provide a novel potential mechanism for the anticancer activities of Dau in human breast cancer.
\end{abstract}

Keywords: dauricine; angiogenesis; insulin-like growth factor-I; hypoxia inducible factor 1a; vascular endothelial growth factor Acta Pharmacologica Sinica (2009) 30: 605-616; doi: 10.1038/aps.2009.8; published online 6th April 2009

\section{Introduction}

Dauricine (Dau; Figure 1), a bisbenzylisoquinoline alkaloid isolated from the rhizome of Menispermum dauri-

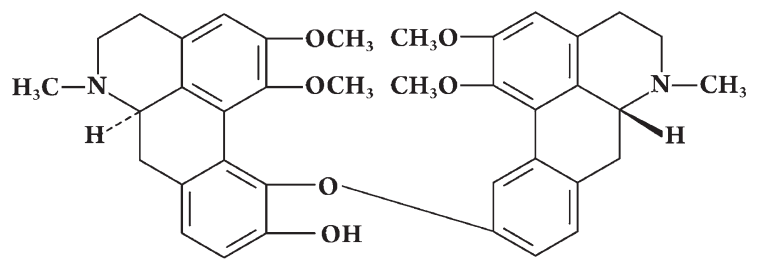

Figure 1. Chemical structure of Dau.

\footnotetext{
\# Now in Department of Biochemistry and Molecular Biology, Guangdong Medical College, Zhanjiang 524023, China.

* Correspondence to Prof Xin ZHOU.

E-mail zhouxjyk@163.com

Received 2008-09-26 Accepted 2009-01-13
}

cum DC, has been found to have antiarrhythmic and antiinflammatory effects ${ }^{[1]}$. Recently, several studies have demonstrated that Dau has potent anticancer activities, including inhibition of growth ${ }^{[2]}$, reduction of drug resistance, and promotion of apoptosis in various tumor cells. However, the effect of Dau on tumor angiogenesis remains unclear.

Angiogenesis - the formation of new vessels from preexisting vasculature - is a fundamental event in the process of tumor growth and metastatic dissemination. It is well known that vascular endothelial growth factor (VEGF) is a pivotal angiogenic factor. Overexpression of VEGF, which has been positively correlated with the cell proliferation marker Ki-67, grade, and stage of breast cancer ${ }^{[3]}$, significantly increased tumor growth and angiogenesis in a murine model of breast cancer $^{[4]}$. Therefore, VEGF is a key target in the therapy of breast cancer.

Hypoxia inducible factor 1 (HIF-1) mediates the expres- 
sion of VEGF and thus plays an important role in tumor angiogenesis. HIF-1 is composed of the HIF- $1 \alpha$ and HIF-1 $\beta$ subunits. Whereas HIF- $1 \beta$ is expressed constitutively, HIF-1 $\alpha$ expression is tightly regulated by oxygen concentration. Under normoxic conditions, HIF- $1 \alpha$ is hydroxylated at two prolyl residues (pro ${ }^{402}$ and pro $^{564}$ ) within an oxygendependent degradation domain (ODD) by $\mathrm{Fe}^{2+}$ and $\mathrm{O}_{2}$-dependent HIF-1 prolyl hydroxylases (HPH), which results in its ubiquitination and subsequent degradation. However, under hypoxic conditions, these steps are blocked, which leads to the accumulation of HIF- $1 \alpha$ and the subsequent activation of genes that are essential to cellular adaptation to low oxygen conditions. These genes include VEGF, erythropoietin and glucose transporter-1. Increasing evidence shows that, under normoxic conditions, HIF- $1 \alpha$ is also induced and activated by non-hypoxic stimuli ${ }^{[5-11]}$ such as growth factors $^{[5-8]}$, cytokines, vascular hormones, viral proteins ${ }^{[9,10]}$, and nicotine ${ }^{[11]}$. Among these stimuli, growth factors are very important. Insulin-like growth factor-I (IGF-I) has been shown to induce HIF-1 $\alpha$ protein expression under normoxic conditions in different cell types ${ }^{[5-8]}$.

HIF- $1 \alpha$ has been demonstrated to be a central regulator of tumor phenotype ${ }^{[12,13]}$. Thus, HIF-1 $\alpha$ may be a possible target for cancer chemoprevention ${ }^{[14]}$. In addition, overexpression of HIF- $1 \alpha$ has been observed in many common cancers, including primary breast cancers, and HIF- $1 \alpha$ expression levels could serve as a novel predictor of poor outcome for both node-negative and node-positive breast tumors ${ }^{[15]}$. Therefore, like VEGF, HIF-1 $\alpha$ may also be an important target in breast cancer therapy, and HIF-1 $\alpha$ and VEGF inhibitors could be developed as potential antitumor agents for breast cancer.

Several alkaloids have been found to inhibit tumor angiogenesis by targeting HIF- $1 \alpha^{[16,17]}$. The alkaloid vincristine (VCR) can induce significant expression of HIF-1a. VCRresistant SGC7901/VCR cells have much higher expression of HIF-1 1 when compared with human gastric cancer SGC7901 cells ${ }^{[18]}$. The effects of various alkaloids on HIF-1 $\alpha$ are different. The effects of Dau, a bisbenzylisoquinoline alkaloid, on HIF-1 $\alpha$ and VEGF expression levels have not yet been reported. Therefore, in this study, we investigated the effects of Dau on IGF-I-induced HIF- $1 \alpha$ and VEGF expression levels in human breast cancer cells (MCF-7). We found that Dau significantly inhibited IGF-I-induced HIF-1 1 protein accumulation and VEGF expression in MCF-7 cells.

\section{Materials and methods}

Drug and reagents Dau (purity $>99 \%$ ) was kindly provided by Prof Xiong-tai GUAN (Guangdong Medical College, Zhanjiang, China). Dau was dissolved in $0.9 \%$ $\mathrm{NaCl}$ to make a stock solution of $1 \mathrm{mmol} / \mathrm{L}$ with a $\mathrm{pH}$ ranging from 6.5 to 6.8. PD98059, LY294002, and rapamycin were purchased from Beyotime Biotechnology Corporation, Shanghai (Shanghai, China) and dissolved in DMSO. The final DMSO concentration of any solution used throughout the study did not exceed $0.1 \%$. Dulbecco's modified Eagle's medium (DMEM), medium 199 and TRIzol $^{\circledR}$ reagent were purchased from Invitrogen Corp (Carlsbad, CA, USA). Recombinant human IGF-I, the protein synthesis inhibitor cycloheximide ( $\mathrm{CHX}$ ), acidic fibroblast growth factor (aFGF) and $\beta$-actin monoclonal antibody were purchased from Sigma (St Louis, MO, USA). Mouse anti-human HIF-1 $\alpha$ monoclonal antibody was purchased from BD Transduction Laboratories (San Diego, CA, USA). Total and phosphorylated extracellular signal-regulated kinase $1 / 2$ (ERK1/2; Thr202/Tyr204) antibodies, Akt $\left(\mathrm{Ser}^{473}\right)$ antibody, and phosphorylated eukaryotic initiation factor 4E (eIF)-binding protein 1 (4E-BP1) antibody were purchased from Santa Cruz Biotechnology (Santa Cruz, CA, USA). Phosphorylated $M_{\mathrm{r}} 70000$ ribosomal protein S6 kinase (p70S6K) antibody was from Signalway Antibody Co, Ltd (Pearland, TX, USA). Horseradish peroxidase (HRP)conjugated secondary antibody was purchased from Pierce (Rockford, IL, USA). The iScript ${ }^{\mathrm{TM}}$ One-step RT-PCR Kit with $S Y B R^{\circledR}$ green was purchased from Bio-Rad (Hercules, CA, USA). The human VEGF ELISA development kit was purchased from Peprotech Inc (Rocky Hill, NJ, USA). The dual luciferase reporter assay system was purchased from Promega (Madison, WI, USA). The 3-(4,5-dimethylthiazol2-yl)-2,5-diphenyltetrazolium bromide (MTT) assay kit, in vitro angiogenesis assay kit, and cell invasion kit were purchased from Chemicon International Inc (Temecula, CA, USA).

Cell culture Human estrogen-responsive breast cancer cells (MCF-7) and human umbilical vein endothelial cells (HUVECs) were obtained from the American Type Culture Collection (ATCC) (Rockville, MD, USA). MCF-7 cells were maintained in DMEM medium supplemented with $10 \%$ fetal bovine serum (FBS), $100 \mathrm{U} / \mathrm{mL}$ penicillin, and $100 \mu \mathrm{g} / \mathrm{mL}$ streptomycin. HUVECs were cultured in medium 199 supplemented with $20 \% \mathrm{FBS}, 100 \mathrm{mmol} / \mathrm{L}$ HEPES, $100 \mathrm{U} / \mathrm{mL}$ penicillin, $100 \mu \mathrm{g} / \mathrm{mL}$ streptomycin, 2 $\mathrm{mmol} / \mathrm{L}$ glutamine, $5 \mathrm{ng} / \mathrm{mL}$ aFGF, and $5 \mathrm{U} / \mathrm{mL}$ heparin. MCF-7 cells and HUVECs were incubated at $37^{\circ} \mathrm{C}$ in a humidified atmosphere with $5 \% \mathrm{CO}_{2}$.

Treatment of cancer cells with Dau Exponentially growing MCF-7 cells (about $80 \%$ confluence) were serum- 
starved for $24 \mathrm{~h}$, followed by pretreatment with different concentrations of Dau $(5,10$, and $20 \mu \mathrm{mol} / \mathrm{L})$ for $1 \mathrm{~h}$ in serumfree medium. Afterward, cells were treated with $40 \mathrm{ng} / \mathrm{mL}$ IGF-I in serum-free medium for $6 \mathrm{~h}$. HIF-1 $\alpha$ protein levels were analyzed by Western blotting. The amount of VEGF protein product in the conditioned medium was determined by ELISA. HIF- $1 \alpha$ and VEGF mRNA levels were detected by real-time PCR. To study the effects of Dau on the half-life or degradation of IGF-I-induced HIF- $1 \alpha$ protein accumulation, MCF-7 cells were pretreated with IGF-I for $6 \mathrm{~h}$ followed by treatment with $10 \mu \mathrm{g} / \mathrm{mL} \mathrm{CHX} \mathrm{to} \mathrm{inhibit} \mathrm{further}$ protein synthesis in the presence or absence of $10 \mu \mathrm{mol} / \mathrm{L}$ Dau for different time periods. HIF-1 $\alpha$ protein levels were determined by Western blotting.

Western blotting The treated and untreated cells were lysed with buffer containing $50 \mathrm{mmol} / \mathrm{L}$ Tris- $\mathrm{HCl}(\mathrm{pH} 7.5)$, $5 \mathrm{mmol} / \mathrm{L}$ EDTA, $150 \mathrm{mmol} / \mathrm{L} \mathrm{NaCl}$, 0.5\% Triton X-100, 10 $\mathrm{mmol} / \mathrm{L}$ sodium fluoride, $20 \mathrm{mmol} / \mathrm{L} \beta$-mercaptoethanol, $250 \mu \mathrm{mol} / \mathrm{L}$ sodium orthovanadate, $1 \mathrm{mmol} / \mathrm{L}$ phenylmethyl sulfonylfluoride (PMSF), and complete protease inhibitor cocktail (Roche, Mannheim, Germany). They were then incubated at $4{ }^{\circ} \mathrm{C}$ for $1 \mathrm{~h}$. The lysates were ultrasonicated and centrifuged at $12000 \mathrm{~g}$ for $10 \mathrm{~min}$. The supernatants were collected and stored at $-70{ }^{\circ} \mathrm{C}$. Protein concentrations were determined by the BCA method. Protein $(50-100 \mu \mathrm{g})$ was separated on a $10 \%$ polyacrylamideSDS gel and electroblotted onto a nitrocellulose membrane. After being blocked with TBS/5\% nonfat dry milk for $2 \mathrm{~h}$, the membranes were incubated overnight at $4{ }^{\circ} \mathrm{C}$ with antibodies against HIF-1a, total or phosphorylated ERK1/2 $\left(\mathrm{Thr}^{202} / \mathrm{Tyr}^{204}\right.$ ) or Akt $\left(\mathrm{Ser}^{473}\right)$, phosphorylated p70S6K (p-p70S6K), or phosphorylated 4E-BP1 (p-4E-BP1), followed by incubation with a horseradish peroxidase (HRP)conjugated secondary antibody $(1: 1000)$ for $45 \mathrm{~min}$ at room temperature. The signals were visualized by the enhanced chemiluminescence detection system (ECL). As a loading control, the blots were reprobed with a specific antibody against human $\beta$-actin (1:5000).

Real-time PCR analysis for HIF-1 $\alpha$ and VEGF mRNA levels Total RNA was isolated from cells using TRIzol ${ }^{\circledR}$ Reagent. Real-time PCR analysis of HIF- $1 \alpha$ and VEGF mRNA levels was performed using the iScript ${ }^{\mathrm{TM}}$ One-step RT-PCR Kit with SYBR ${ }^{\circledR}$ Green, according to the manufacturer's instructions. The following primers were designed for real-time PCR: HIF-1 $\alpha$, forward 5'-GTTTACTAAAGGACAAGTCACC-3' and reverse 5'-TTCTGTTTGTTGAAGGGAG-3' ${ }^{[19]}$; VEGF, forward 5'-TCTACCTCCACCATGCCAAGT-3' and reverse 5'-GATGATTCTGCCCTCCTCCTT-3 ${ }^{\prime 20]}$; $\beta$-actin, for- ward 5'-TCAAGATCATTGCTCCTCCTG-3' and reverse 5'-CTGCTTGCTGATCCACATCTG-3' ${ }^{\text {[21] }}$. All the primers were synthesized by Shanghai Sangon Biological Engineering Technology and Services Co, Ltd (Shanghai, China). The thermocycling conditions were as follows: $50^{\circ} \mathrm{C}$ for $10 \mathrm{~min}$, $95^{\circ} \mathrm{C}$ for $5 \mathrm{~min}$, followed by 40 cycles at $95^{\circ} \mathrm{C}$ for $10 \mathrm{~s}$, and $53{ }^{\circ} \mathrm{C}$ for $30 \mathrm{~s}$ (HIF- $\left.1 \alpha\right)$ or $60^{\circ} \mathrm{C}$ for $30 \mathrm{~s}$ (VEGF). The relative HIF-1 $\alpha$ and VEGF mRNA levels were normalized to $\beta$-actin. The experiment was repeated in triplicate.

ELISA assay for VEGF production The concentration of VEGF protein in the conditioned medium of the untreated and treated cells was determined using the human VEGF ELISA development kit, according to the manufacturer's instructions. Results were normalized to cell number $\left(2 \times 10^{5}\right.$ cells/well). The experiment was repeated in triplicate.

Transient transfection and luciferase reporter assays MCF-7 cells were transiently transfected with $0.5 \mu \mathrm{g}$ of VEGF reporter plasmids for $4 \mathrm{~h}$ in serum-free medium. One-tenth microgram of the Renilla luciferase pRL-TK plasmid was co-transfected as an indicator for normalization of transfection efficiency. After recovery overnight, cells were starved for $24 \mathrm{~h}$ in serum-free medium. Serum-starved cells were subsequently pretreated with different concentrations of Dau for $1 \mathrm{~h}$ in fresh serum-free medium. This was followed by exposure to IGF-I for $6 \mathrm{~h}$ before harvesting cell lysates for luciferase assays by using the Dual Luciferase Reporter Assay System. The experiment was repeated in triplicate.

In vitro angiogenesis assay Angiogenesis in vitro was analyzed according to the manufacturer's instructions. Briefly, after 96-well cell culture plates had been coated with ECMatrix $^{\mathrm{TM}}$, HUVECs $\left(5 \times 10^{3}\right.$ cells/well $)$ were seeded onto the surface of the polymerized ECMatrix ${ }^{\mathrm{TM}}$ with the conditioned medium derived from MCF-7 cells in the presence or absence of Dau. The cells were incubated at $37^{\circ} \mathrm{C}$ for $6-8 \mathrm{~h}$, and tube formation was observed under a phase-contrast microscope. The total tube length in three random viewfields per well was measured, and the average value was calculated using Metamorph Imaging Series software. HUVEC cell viability was determined by MTT assay after treatment, as described above. The experiment was repeated in triplicate.

In vitro cell invasion assay A cell invasion kit was used for the cell invasion assay, according to the manufacturer's instructions. HUVECs $\left(5 \times 10^{4}\right.$ cells $)$ were resuspended in $300 \mu \mathrm{L}$ of serum-free medium and seeded onto the interior side of inner chambers containing a polycarbonate membrane of $8-\mu \mathrm{m}$ pore size and a thin layer of rehydrated extracellular matrix. Five hundred microliters of serumfree medium containing IGF-I, at a final concentration of $40 \mathrm{ng} / \mathrm{mL}$, was added to the lower chamber. To determine 
the effect of Dau on HUVEC invasion, different concentrations of Dau were added to the lower chamber. The invasion chamber was incubated for $48 \mathrm{~h}$ at $37^{\circ} \mathrm{C}$. The non-invading cells and the extracellular matrix gel from the interior side of the inserts were gently removed using a cotton-tipped swab. The invasive cells that migrated through the gel insert to the lower surface of the membrane were stained and photographed using a computer imaging system. Afterward, the stained cells were extracted with $200 \mu \mathrm{L}$ of extract solution, and the absorbance was determined at $562 \mathrm{~nm}$. The experiment was repeated in triplicate.

Cell viability assay MCF-7 cells or HUVECs were seeded in 96-well plates $\left(10^{4}\right.$ cells/well). Viable cells were determined using the MTT assay kit, according to the manufacturer's instructions. The experiment was repeated in triplicate.

Statistical analysis Data are presented as the mean \pm SD for three separate experiments. One-way ANOVA and Bonferroni were employed for statistical analysis using SPSS 11.0 for Windows software. $P<0.05$ was considered to be statistically significant.

\section{Results}

Dau inhibited IGF-I-induced HIF-1 $\propto$ protein accumu-

A

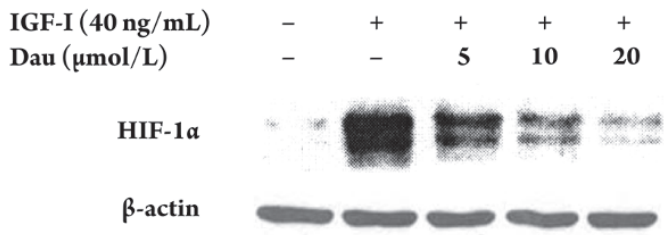

C

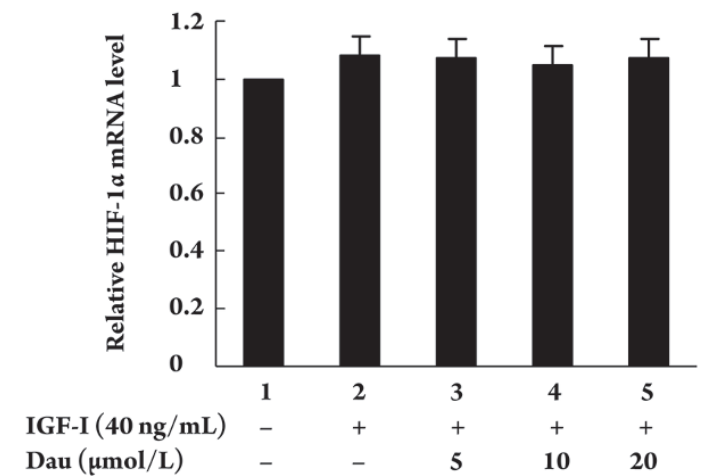

lation in MCF-7 cells Previous studies have demonstrated that IGF-I can increase HIF-1 $\alpha$ protein expression ${ }^{[5-8]}$. Our results also showed that IGF-I remarkably induced HIF-1 $\alpha$ protein accumulation in MCF-7 cells (Figure 2A). To study the effects of Dau on IGF-I-induced HIF-1 $\alpha$ protein accumulation, serum-starved MCF-7 cells were pretreated for $1 \mathrm{~h}$ with different concentrations of Dau, followed by incubation with IGF-I for $6 \mathrm{~h}$. We found that Dau inhibited IGF-Iinduced HIF-1 $\alpha$ protein accumulation in a dose-dependent manner (Figure 2A). To rule out the possibility that the inhibitory effect of Dau on the HIF-1 $\alpha$ protein was due to its cellular toxicity, cell viability was determined using MTT assay. No obvious changes in cell viability were observed in MCF-7 cells after treatment as described above (Figure 2B). In addition, serum-starved MCF-7 cells were pretreated for $1 \mathrm{~h}$ with $10 \mu \mathrm{mol} / \mathrm{L}$ Dau, followed by incubation with IGF-I for 1,6 , and $16 \mathrm{~h}$, respectively. No significant difference in HIF-1 $\alpha$ protein expression was observed between $6 \mathrm{~h}$ and $16 \mathrm{~h}$ (data not shown), but cell viability was significantly decreased when cells were treated with $10 \mu \mathrm{mol} / \mathrm{L}$ Dau for $16 \mathrm{~h}$ (data not shown). Therefore, incubation for $6 \mathrm{~h}$ was chosen in this study. To investigate whether Dau inhibited IGF-I-induced HIF-1 $\alpha$ protein accumulation was the result of transcriptional inhibition, HIF-1 $\alpha$ mRNA levels were

B

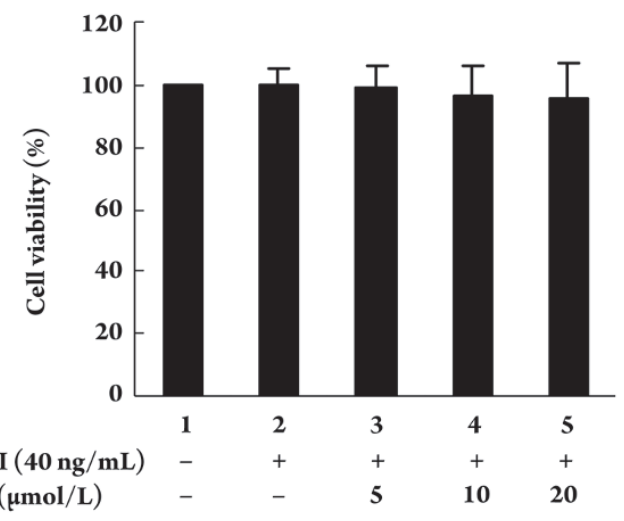

D

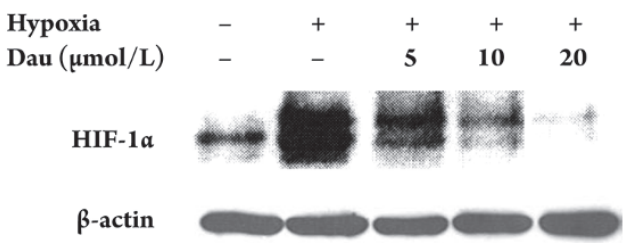

Figure 2. Dau inhibited IGF-I-induced HIF-1 $\alpha$ protein accumulation in MCF-7 cells but had no effect on HIF- $1 \alpha$ mRNA levels. (A and C) Serumstarved MCF-7 cells were pretreated with different concentrations of Dau for $1 \mathrm{~h}$, followed by incubation with IGF-I (40 ng/mL) for 6 h. HIF$1 \alpha$ protein and mRNA levels were determined by Western blotting (A) and real-time PCR (C), respectively. (B) Cell viability was analyzed using the MTT assay. (D) MCF-7 cells were pretreated with different concentrations of Dau for $1 \mathrm{~h}$, followed by exposure to hypoxia for $6 \mathrm{~h}$. Western blotting was performed to determine HIF- $1 \alpha$ protein levels. Data represent mean \pm SD of three independent experiments. 
determined by real-time PCR. As shown in Figure 2C, there was no apparent change in HIF-1 $\alpha$ mRNA levels in MCF-7 cells after incubation with IGF-I for $6 \mathrm{~h}$ (Figure 2C). Treatment of MCF-7 cells with different concentrations of Dau had no obvious effect on HIF-1 $\alpha$ mRNA expression in response to IGF-I (Figure 2C).

To investigate whether Dau also inhibits hypoxiainduced expression of HIF-1 $\alpha$, MCF-7 cells were pretreated with different concentrations of Dau for $1 \mathrm{~h}$, followed by exposure for $6 \mathrm{~h}$ to hypoxia $\left(1 \% \mathrm{O}_{2}\right)$ in a hypoxic chamber with an auto purge airlock (Coy Laboratory Products Inc, Grass Lake, MI, USA). Our results showed that Dau also inhibited hypoxia-induced HIF-1 $\alpha$ protein expression (Figure 2D).

Dau inhibited IGF-I-induced VEGF expression and transcriptional activation in MCF-7 cells VEGF is a major downstream target gene of HIF-1 $\alpha$. Accumulating evidence has demonstrated that IGF-I could significantly increase HIF-1 $\alpha$-mediated VEGF expression ${ }^{[5-8]}$. We also found that IGF-I enhanced VEGF protein secretion (Figure 3A) and mRNA expression (Figure 3B). To determine whether Dau can inhibit IGF-I-induced VEGF secretion in MCF-7 cells, serum-starved MCF-7 cells were pretreated for $1 \mathrm{~h}$ with different concentrations of Dau, followed by incubation with IGF-I for $6 \mathrm{~h}$. VEGF protein and mRNA levels were determined by ELISA and real-time PCR, respectively. Our results indicated that Dau reduced IGF-I-induced VEGF protein secretion (Figure $3 \mathrm{~A}$ ) and mRNA expression (Figure $3 \mathrm{~B})$ in a dose-dependent manner $(P<0.01)$. To further confirm the effect of Dau on VEGF transcriptional activation, MCF-7 cells were transiently transfected with a luciferase reporter plasmid (pGL2-Luc) harboring the human VEGF promoter region, followed by treatment with various concentrations of Dau exposed to IGF-I for $6 \mathrm{~h}$. Our results showed that IGF-I remarkably enhanced VEGF promoter activity (Figure $3 \mathrm{C}, \mathrm{P}<0.01$ ) and that Dau significantly inhibited this effect in a dose-dependent manner (Figure $3 C, P<0.01$ ). No apparent changes in cell morphology or toxicity in MCF-7 cells were found after the treatment described above (data not shown).

Dau decreased IGF-I-induced HIF- $1 \alpha$ and VEGF protein expression levels by interfering with the PI-3K/Akt/ mTOR signaling pathway and partially suppressed IGFI-induced HIF-1 $\alpha$ protein accumulation by inhibiting protein synthesis To examine the effects of Dau on activation of Akt and ERK1/2, serum-starved MCF-7 cells were pretreated for $1 \mathrm{~h}$ with different concentrations of Dau, followed by incubation with IGF-I for $1 \mathrm{~h}$. Our results showed that Dau

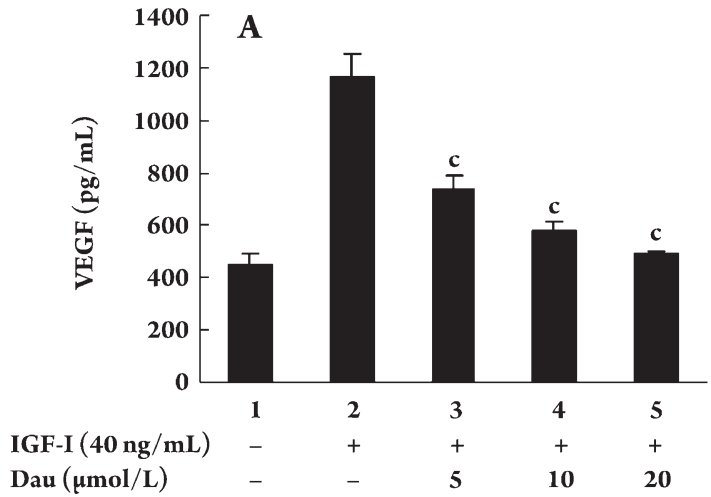

$\operatorname{Dau}(\mu \mathrm{mol} / \mathrm{L})$

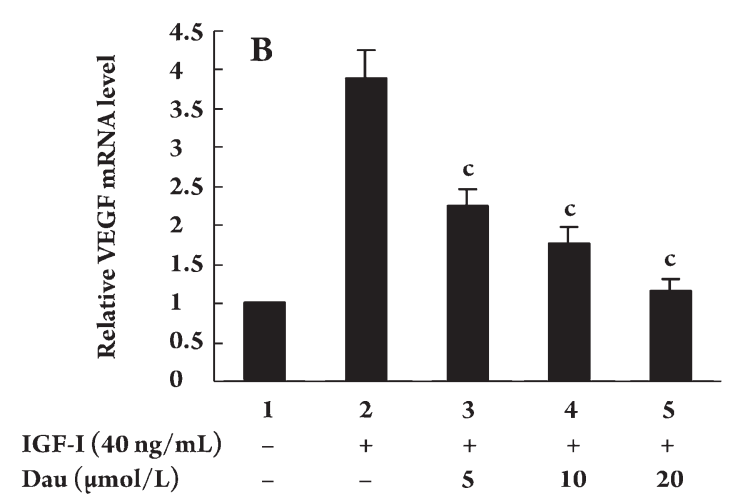

Figure 3. Dau inhibited VEGF expression and transcriptional activation in MCF-7 cells in response to IGF-I. (A and B) Serum-starved MCF-7 cells were pretreated for $1 \mathrm{~h}$ with different concentrations of Dau, followed by exposure to IGF-I $(40 \mathrm{ng} / \mathrm{mL})$ for $6 \mathrm{~h}$. VEGF protein production in the conditioned medium was determined by ELISA (A). VEGF mRNA expression was analyzed by real-time PCR (B). (C) Following transient transfection with VEGF promoter reporter plasmids, MCF-7 cells were pretreated with various concentrations of Dau for $1 \mathrm{~h}$ and then exposed to IGF-I for $6 \mathrm{~h}$. Luciferase activities were analyzed using the Dual-Luciferase Assay Kit. Data represent mean $\pm \mathrm{SD}$ of three independent experiments. ${ }^{c} P<0.01$ vs drug-untreated control (IGF-I only, lane 2). Lane 2 was compared with lane $1, P<0.01$. 
dramatically decreased p-Akt levels (Figure 4A). But Dau had no obvious inhibitory effect on ERK1/2 activation (Figure 4B). LY294002 (50 $\mu \mathrm{mol} / \mathrm{L})$, a specific inhibitor of PI-3K, significantly inhibited Akt activation (Figure 4A). PD98059 (50 $\mu \mathrm{mol} / \mathrm{L}$ ), a specific inhibitor of ERK1/2, dramatically downregulated p-ERK1/2 levels (Figure 4B). To further confirm our results, we next pretreated serum-starved MCF-7 cells with various concentrations of PD98059 or LY294002 for $1 \mathrm{~h}$, followed by exposure to IGF-I for $6 \mathrm{~h}$. Our results showed that IGF-I-induced HIF- $1 \alpha$ protein accumulation and VEGF protein secretion were inhibited by LY294002 (Figure 4C, 4D) but not by PD98059 (Figure 4E, 4F). Taken together, these results suggested that Dau inhibited IGF-I-induced HIF-1 $\alpha$ and VEGF protein expression in MCF-7 cells mainly via PI3K/Akt pathway.

Previous studies have demonstrated that IGF-I-mediated activation of PI-3K/Akt is essential to regulate HIF-1 $\alpha$ protein synthesis via phosphorylating protein translational regulators, including $\mathrm{p} 70 \mathrm{~S} 6 \mathrm{~K}$ and $4 \mathrm{E}-\mathrm{BP} 1^{[23,24]}$. Thus, we next investigated the effects of Dau on the protein translational machinery. Our results showed that IGF-I stimulated activation of p70S6K and 4E-BP1 in MCF-7 cells (Figure 5A, lane 2 vs lane 1), and Dau could remarkably inhibited IGFI-induced activation of p70S6 $\mathrm{K}$ in a dose-dependent manner (Figure 5A). Meanwhile, Dau at a concentration of 20 $\mu \mathrm{mol} / \mathrm{L}$ could inhibit IGF-I-induced activation of 4E-BP1. To further confirm these results, we pretreated serumstarved MCF-7 cells with rapamycin to inhibit mammalian target of rapamycin (mTOR), which is an upstream target of p70S6K and 4E-BP1, followed by exposure to IGF-I for $6 \mathrm{~h}$. Our results showed that rapamycin strongly suppressed IGFI-induced HIF- $1 \alpha$ protein accumulation (Figure 5B) and VEGF secretion (Figure 5C, $P<0.01$ ). In addition, we found that LY294002 (a specific inhibitor of PI3K) and rapamycin (a specific inhibitor of mTOR) could dramatically inhibit IGF-I-induced expression of p-p70S6K and p-4E-BP1 protein in MCF-7 cells (Data not shown). Taken together, these results indicated that Dau decreased IGF-I-induced HIF-1 $\alpha$
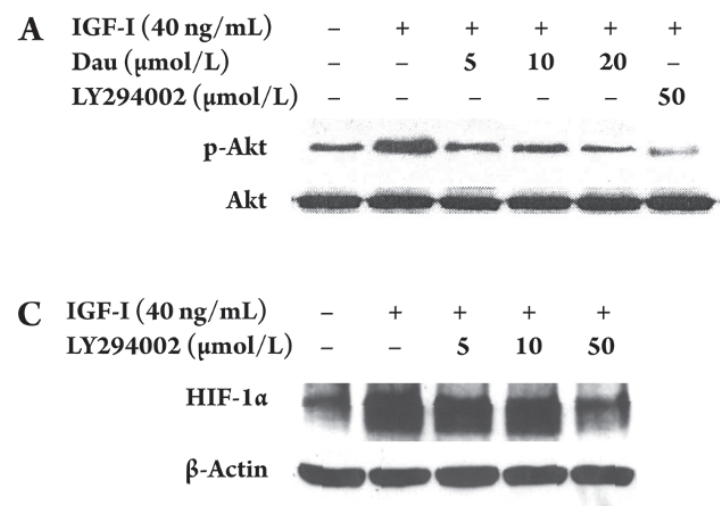

E IGF-I $(40 \mathrm{ng} / \mathrm{mL})-\quad+\quad+\quad+\quad+$ $\operatorname{PD98059}(\mu \mathrm{mol} / \mathrm{L}) \quad-\quad-\quad 5 \quad 10 \quad 50$

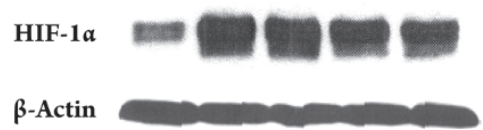

$\mathbf{F}$

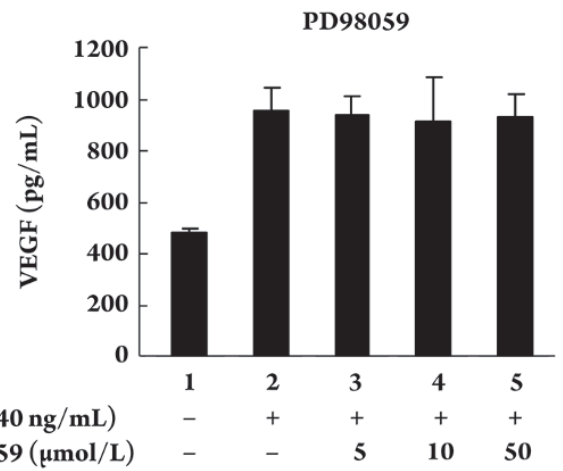

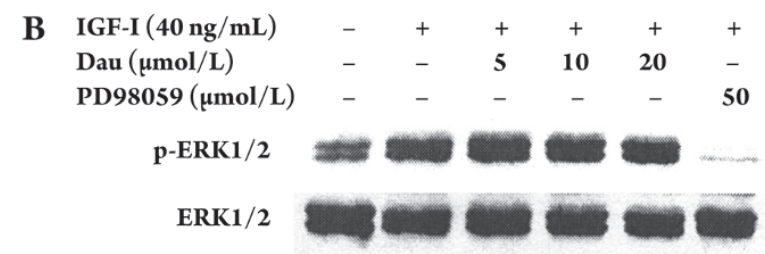

D

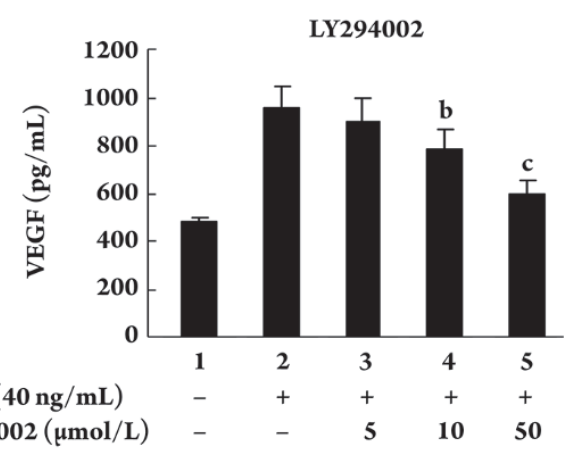

Figure 4. Dau inhibited IGF-I-induced HIF- $1 \alpha$ and VEGF protein expression mainly by interfering with PI-3K/Akt. (A and B) Serum-starved MCF-7 cells were pretreated for $1 \mathrm{~h}$ with different concentrations of Dau, followed by incubation with IGF-I $(40 \mathrm{ng} / \mathrm{mL})$ for $6 \mathrm{~h}$. Phosphorylated Akt (p-Akt, A) and phosphorylated ERK1/2 (p-ERK1/2, B) levels were determined by Western blotting. (C-F) Serum-starved MCF-7 cells were pretreated with various concentrations of LY294002 or PD98059 for $1 \mathrm{~h}$, followed by incubation with IGF-I $(40 \mathrm{ng} / \mathrm{mL})$ for $6 \mathrm{~h}$. HIF-1 $\alpha$ protein levels were analyzed by Western blotting (C, E), and VEGF production in the conditioned medium was determined by ELISA (D, F). Data represent mean \pm SD of three independent experiments. ${ }^{b} P<0.05,{ }^{c} P<0.01$ vs druguntreated control (IGF-I only, lane 2). 
A

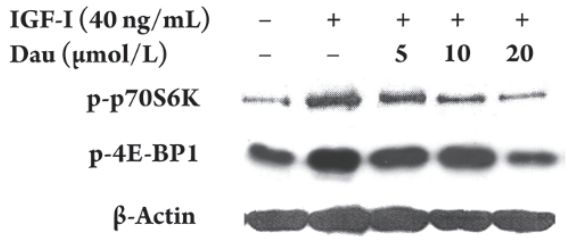

B IGF-I $(40 \mathrm{ng} / \mathrm{mL})-\quad+\quad+\quad+\quad+$ Rapamycin (nmol/L) $\quad-\quad \begin{array}{llll}\mathrm{L} & 5 & 10 & 50\end{array}$

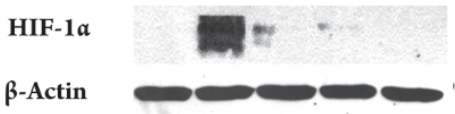

C

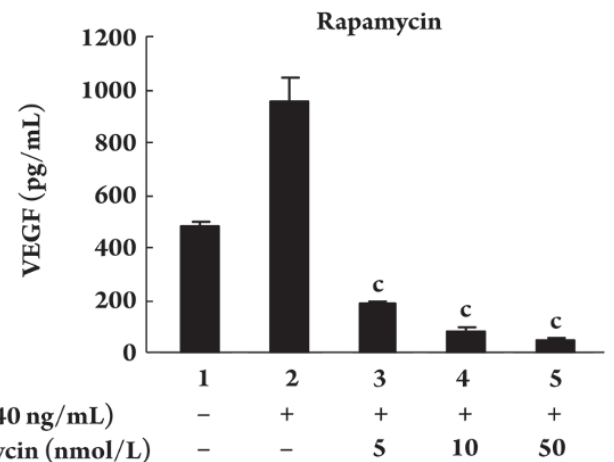

Figure 5. Dau inhibited p70S6K and 4E-BP1 phosphorylation and rapamycin, a specific inhibitor of mTOR, suppressed IGF-I-induced HIF- $1 \alpha$ protein accumulation. (A) Serum-starved MCF-7 cells were pretreated for $1 \mathrm{~h}$ with different concentrations of Dau, followed by incubation with IGF-I $(40 \mathrm{ng} / \mathrm{mL})$ for $6 \mathrm{~h}$. Phosphorylated p70S6K and 4E-BP1 levels were determined by Western blotting. (B, C) Serumstarved MCF-7 cells were pretreated with various concentrations of rapamycin for $1 \mathrm{~h}$, followed by incubation with IGF-I $(40 \mathrm{ng} / \mathrm{mL})$ for $6 \mathrm{~h}$. HIF-1 $\alpha$ protein levels were analyzed by Western blotting (B), and VEGF production in the conditioned medium was determined by ELISA (C). Data represent mean $\pm S D$ of three independent experiments. ${ }^{c} P<0.01$ vs drug-untreated control (IGF-I only, lane 2).

and VEGF protein expression levels in MCF-7 cells mainly by interfering with PI3K/Akt/mTOR signaling pathway. Dau could also partially suppress HIF- $1 \alpha$ protein synthesis in response to IGF-I.

Dau inhibited IGF-I-induced HIF-1 1 a protein accumulation in MCF-7 cells by promoting HIF-1a protein degradation To explore whether Dau simultaneously promotes HIF-1 $\alpha$ protein degradation along with inhibiting its synthesis, serum-starved MCF-7 cells were exposed to IGF-I for $6 \mathrm{~h}$, followed by treatment with CHX to block ongoing protein synthesis in the presence or absence of $10 \mu \mathrm{mol} /$ L Dau for different time intervals. Our results showed that Dau promoted the degradation of IGF-I-induced HIF- $1 \alpha$ protein (Figure 6B, 6C) when compared with treatment with
A

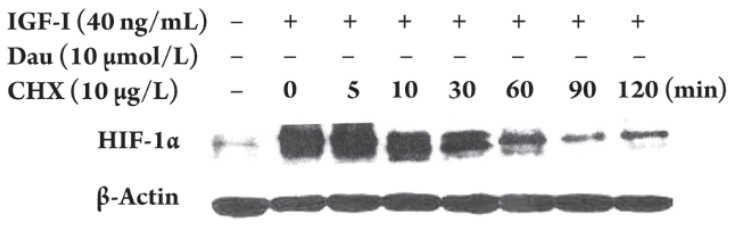

B

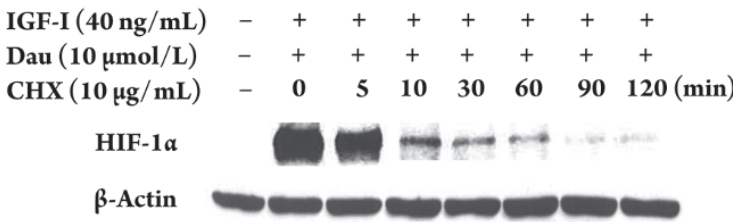

C

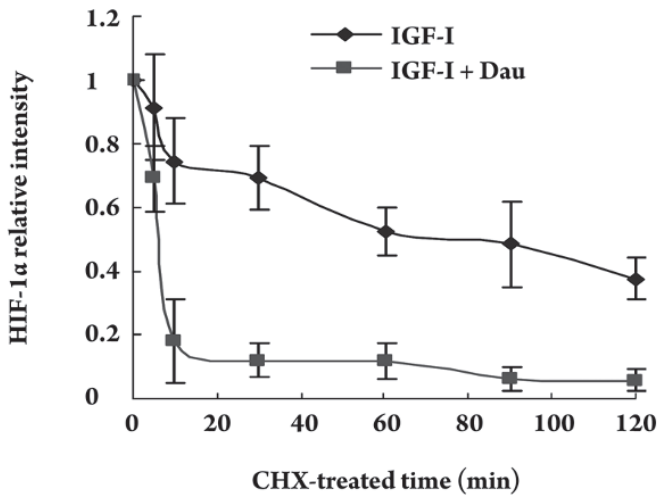

Figure 6. Dau promoted the degradation of IGF-I-induced HIF$1 \alpha$ protein in MCF-7 cells. (A, B) Serum-starved MCF-7 cells were exposed to IGF-I ( $40 \mathrm{ng} / \mathrm{mL}$ ) for $6 \mathrm{~h}$, followed by treatment with $\mathrm{CHX}$ $(10 \mu \mathrm{g} / \mathrm{mL})$ in the presence or absence of $10 \mu \mathrm{mol} / \mathrm{L}$ Dau for different periods of time. HIF-1 1 p protein levels were determined by Western blotting. (C) Quantitative densitometric analysis of results from A and B. The HIF- $1 \alpha$ densitometry data were normalized to that of the druguntreated control (IGF-I only, lane 2). Calculation of the HIF-1 $\alpha$ halflife was performed by the SPSS 11.0 Regression Program. All results represent three independent experiments.

CHX alone (Figure 6A, 6C). The half-life of HIF-1 $a$ protein in the cells pretreated with $10 \mu \mathrm{mol} / \mathrm{L} \mathrm{Dau}(\mathrm{Dau}+\mathrm{CHX})$ is $6.51 \pm 1.69 \mathrm{~min}$, which was much shorter than that in cells treated with CHX alone $(81.39 \pm 10.18 \mathrm{~min})$. These results suggested that Dau also inhibited IGF-I-induced HIF-1 $\alpha$ protein expression by promoting its degradation.

Dau inhibited tube formation in vitro Our results also showed that the conditioned medium derived from MCF-7 cells treated with IGF-I obviously stimulated HUVECs to form capillary tube-like structures on matrigels as compared with control (Figure 7A-a vs Figure 7A-b; upper panel). To confirm the anti-angiogenic effects of Dau, we observed the effects of different concentrations of Dau on the formation of capillary tube-like structures in vitro. We found that 
different concentrations of Dau inhibited tube formation (Figure 7A-c-7A-e). In particular, $20 \mu \mathrm{mol} / \mathrm{L}$ Dau almost completely abrogated tube formation (Figure 7A-e). The total tube length in the $10 \mu \mathrm{mol} / \mathrm{L}$ or $20 \mu \mathrm{mol} / \mathrm{L}$ Dautreated group was much longer than that in the control group $(P<0.01$, Figure $7 B)$. To determine whether Dau inhibited HUVEC tube formation directly, we observed the effects on tube formation of the conditioned medium from the control (drug-untreated control; IGF-I only) plus $20 \mu \mathrm{mol} / \mathrm{L}$ Dau. Our results showed that $20 \mu \mathrm{mol} / \mathrm{L}$ Dau slightly inhibited tube formation in a direct fashion (Figure 7A-f $v s$ Figure 7A-b). However, no statistical significance was found in total tube length between the conditioned medium from the control plus Dau and the conditioned medium from the control only (IGF-I only; $P>0.05$ ). In addition, the total tube length in the conditioned medium from the control plus $20 \mu \mathrm{mol} / \mathrm{L}$ Dau was much longer than that in the conditioned medium derived from MCF-7 cells treated with IGF-I plus $20 \mu \mathrm{mol} / \mathrm{L}$ Dau $(P<0.01)$. To exclude the possibility that the inhibitory effect of Dau on tube formation was due to its cytotoxic
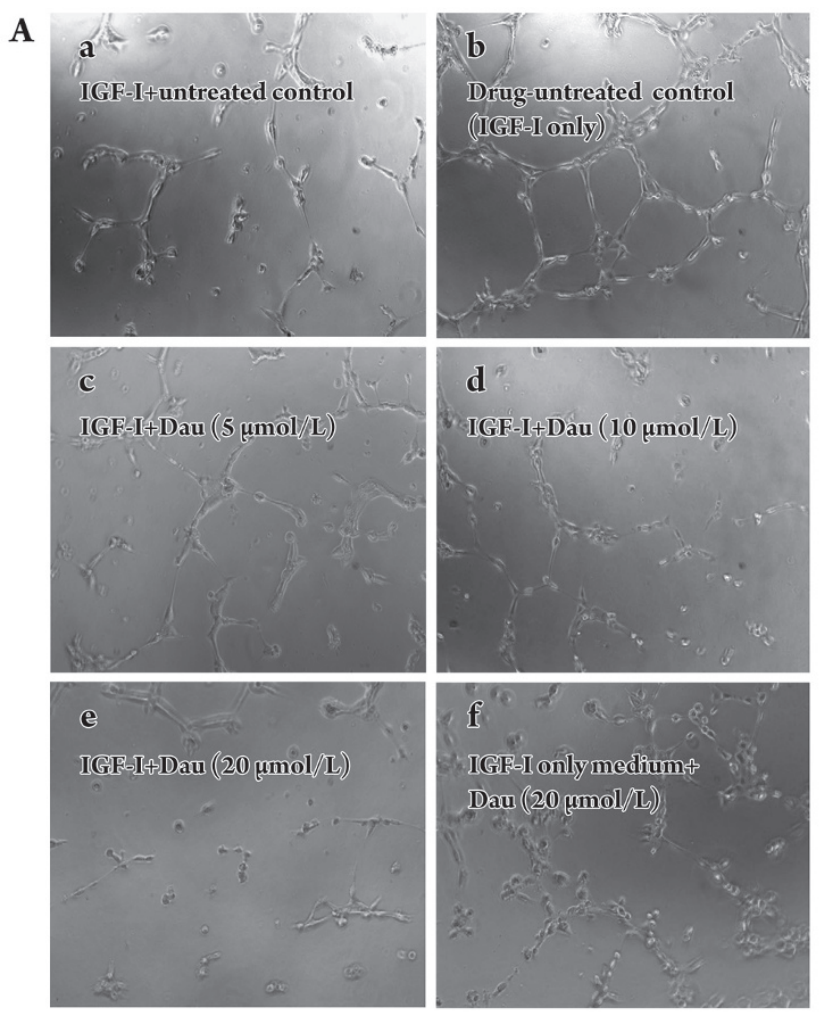

activity, HUVEC viability was determined using the MTT assay. There were no obvious changes in cell viability in the HUVECs after treatment under experimental conditions (Figure 7C). Therefore, our results demonstrated that the inhibitory effect of Dau on tube formation was not due to its direct toxic effects on HUVECs.

Dau inhibited IGF-I-induced invasion of HUVECs in vitro To investigate whether Dau has a direct effect on the invasion of HUVECs, an in vitro assay was performed. IGF-I promoted the invasion of HUVECs (Figure 8A, upper right panel; Figure $8 \mathrm{~B}$, lane 2). Dau at a concentration of 10 $\mu \mathrm{mol} / \mathrm{L}$ or $20 \mu \mathrm{mol} / \mathrm{L}$ significantly suppressed the IGF-I-induced HUVEC invasion (Figure 8B; $P<0.01$ ). These results indicated that Dau had a direct effect on IGF-I-induced invasion of HUVECs.

\section{Discussion}

Previous studies have found that Dau is an antagonist of calcium ion $\left(\mathrm{Ca}^{2+}\right)$ and calmodulin (CaM). Recently,

B

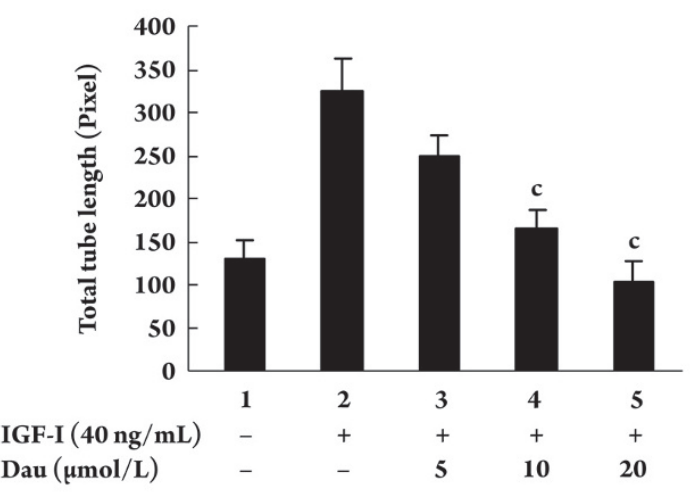

C

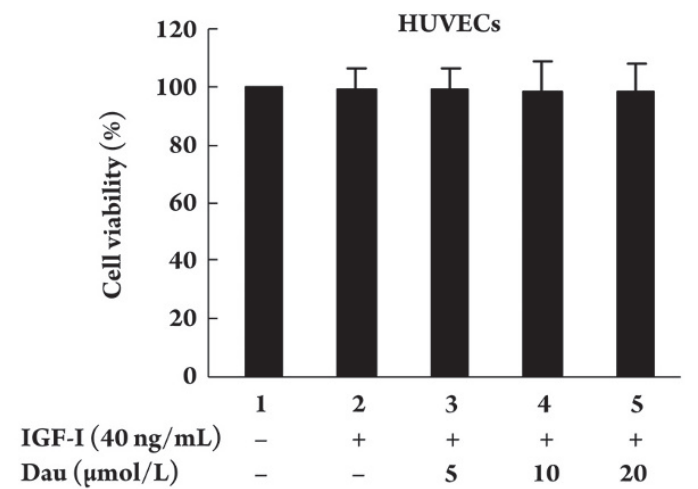

Figure 7. Dau inhibited tube formation in vitro. (A)HUVECs $\left(5 \times 10^{3}\right.$ cells/well) were seeded onto the surface of 96 -well cell culture plates precoated with polymerized ECMatrix ${ }^{\mathrm{TM}}$ and then incubated at $37^{\circ} \mathrm{C}$ for 6 to $8 \mathrm{~h}$ in the conditioned medium derived from MCF-7 cells (a-e) or in the conditioned medium of control (drug-untreated control, IGF-I only) plus $20 \mu \mathrm{mol} / \mathrm{L} \mathrm{Dau}(\mathrm{f})$. The tube formation was observed under a phasecontrast microscope $(\times 100)$. These figures are representative of the results from three separate experiments. (B) The total tube length of each treatment was quantified by the software, Metamorph Imaging Series. (C) Cell viability was analyzed using the MTT method. Data represent mean \pm SD of three independent experiments. ${ }^{c} P<0.01$ vs drug-untreated control (IGF-I only, lane 2 ). 
A
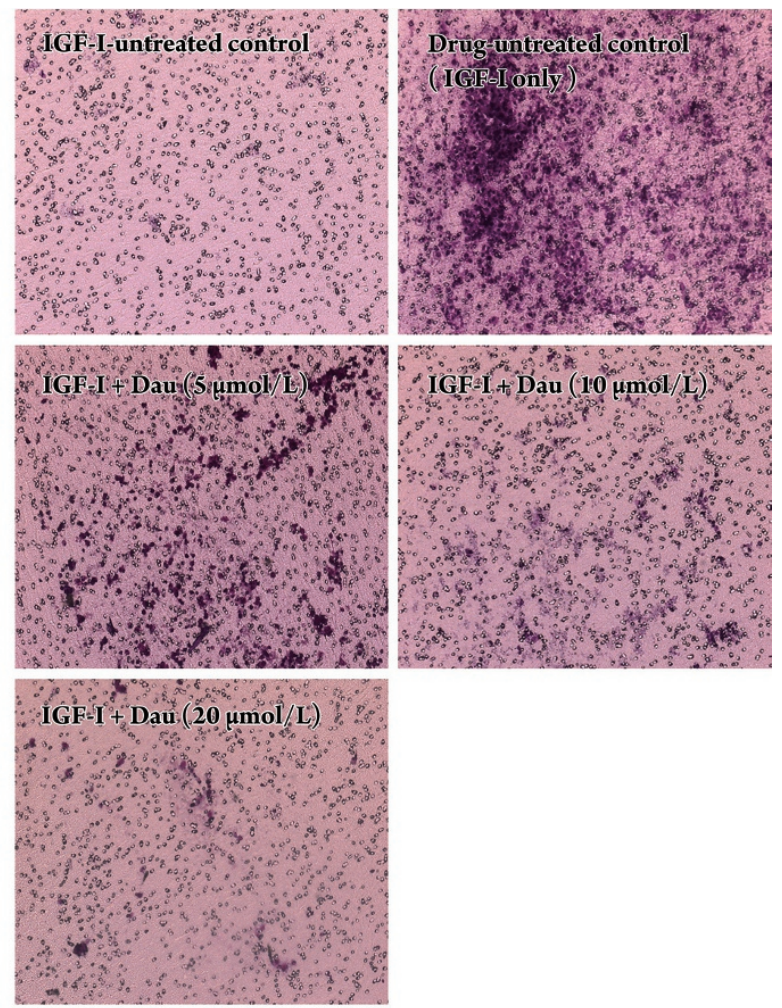

B

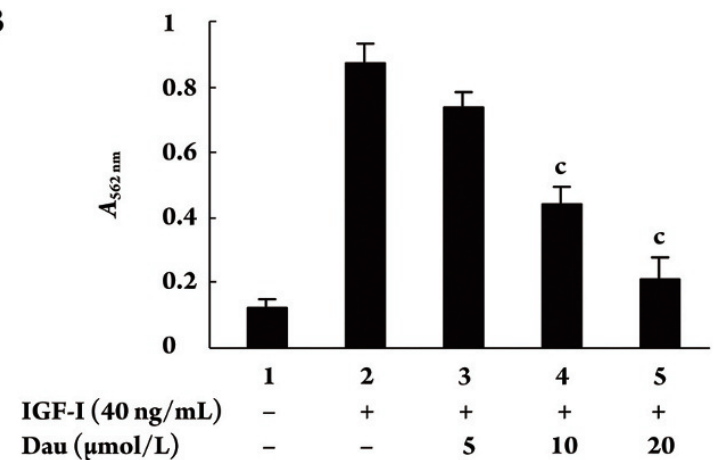

Figure 8. Effect of Dau on IGF-I-induced invasion of HUVECs in vitro. (A) HUVECs $\left(5 \times 10^{4}\right.$ cells $)$ were added to the inner chamber of the insert in $300 \mu \mathrm{L}$ of serum-free media. $500 \mu \mathrm{L}$ of serum-free media containing IGF-I, at a final concentration of $40 \mathrm{ng} / \mathrm{mL}$, was added to the lower chamber. The cells were cultured for $48 \mathrm{~h}$ at $37^{\circ} \mathrm{C}$ in the presence or absence of Dau. The invasive cells that migrated from the upper to the lower surface of the membrane were stained and photographed using a computer imaging system. (B) The stained invasive cells were extracted with $200 \mu \mathrm{L}$ of extract solution, and their absorbance was determined at $562 \mathrm{~nm}$. Data represent mean \pm SD of three independent experiments. ${ }^{c} P<0.01$ vs drug-untreated control (IGF-I only, lane 2).

$\mathrm{Ca}^{2+}$ has been found to play specific roles in the regulation of angiogenesis ${ }^{[25]}$. Therefore, Dau may also have a role in angiogenesis, which is the process of new blood vessel formation by endothelial cells. The invasion of endothelial cells is one of the pivotal processes in the formation of new blood vessels. In the present study, we demonstrated that Dau had a direct inhibitory effect on IGF-I-induced invasion of HUVECs in vitro (Figure 8). Additionally, our results showed that Dau at a concentration of $10 \mu \mathrm{mol} / \mathrm{L}$ or $20 \mu \mathrm{mol} / \mathrm{L}$ in the conditioned medium derived from breast cancer MCF-7 cells could inhibit HUVEC tube formation in vitro (Figure 7 ). These results suggest that Dau may have antiangiogenic effect on breast cancer.

In this study, we found the conditioned medium derived from breast cancer MCF-7 cells treated with IGF-I obviously stimulated HUVECs tube formation in vitro. We wondered whether the tube formation was induced by IGF-I directly or by other genes. Previous studies have demonstrated that IGF-I can enhance the expression of VEGF ${ }^{[5-8]}$, which plays a central role in the process of angiogenesis. Our results also showed that IGF-I induced VEGF expression and transcriptional activation (Figure 3). Therefore, according to previous studies and our results, we speculated that IGF-I in the conditioned medium derived from breast cancer MCF-7 cells stimulated the tube formation by promoting the expression of VEGF, which needs to be further researched.

VEGF has been found to be a target gene for the estrogen receptor and to contribute to breast cancer progression ${ }^{[4,26]}$. Thus, VEGF could be used as a therapeutic target for breast cancer. Our results showed that Dau significantly inhibited IGF-I-induced VEGF protein secretion (Figure 3A) and mRNA levels (Figure 3B) in breast cancer cells (MCF-7). Moreover, we further found that Dau remarkably inhibited the activity of IGF-I-induced VEGF promoter (Figure 3C), which contains hypoxia-response elements (HREs) and thus can be transactivated by HIF- $1 \alpha$. We also wanted to determine whether Dau had an effect on HIF-1 $\alpha$. In this study, we demonstrated that Dau inhibited IGF-I-induced HIF-1 $\alpha$ protein expression in MCF-7 cells (Figure 2A) and that this effect was not due to its cellular toxicity (Figure $2 B$ ). Since the expression of HIF-1 $\alpha$ in most solid tumors is mainly induced by hypoxia, we wanted to further investigate the effect of Dau on the hypoxia-induced expression of HIF-1a in MCF-7 cells. We demonstrated that Dau also inhibited hypoxia-induced HIF-1 $a$ protein expression in MCF-7 cells (Figure 2D). These findings indicate that Dau may have antiangiogenic properties in breast cancer by inhibiting HIF-1a protein accumulation and VEGF expression.

Previous studies have shown that growth factors, including IGF-I, had no effect on HIF-1 $\alpha$ mRNA expression in a variety of cancer cells ${ }^{[19,20,27,28]}$. Recently, however, Mark et al reported 
that IGF-I treatment led to increased HIF-1 $\alpha$ mRNA levels in the retinal pigment epithelium (RPE) cells ARPE-19 $9^{[5]}$. In the present study, IGF-I did not obviously up-regulate HIF-1 $\alpha$ mRNA levels in MCF-7 cells (Figure 2C). Previous studies (ours and others') have demonstrated that several natural products have no effect on HIF-1 $\alpha$ mRNA levels, although they can inhibit HIF-1 $\alpha$ protein accumulation ${ }^{[8,29,30]}$. Similarly, we also found that Dau at any concentration did not significantly affect HIF- $1 \alpha$ mRNA expression in response to IGF-I (Figure 2C), suggesting that Dau inhibited IGF-I-induced HIF-1 $\alpha$ protein accumulation via some post-transcriptional mechanism(s).

Accumulating evidence has demonstrated that PI-3K/ Akt and/or ERK1/2 signaling pathways were involved in IGF-I-induced HIF- $1 \alpha$ and VEGF expression in various cancer cells $^{[19,20,28,29]}$. To further explore the molecular mechanisms by which Dau inhibited HIF-1 $\alpha$ protein accumulation and VEGF expression in MCF-7 cells, we investigated the effects of Dau on the activation of Akt and ERK1/2. Our results showed that Dau suppressed IGF-I-induced Akt activation (Figure 4A) but had no obvious effect on ERK1/2 phosphorylation (Figure 4B). In addition, we further demonstrated that the specific Akt inhibitor LY294002 suppressed HIF-1a protein accumulation (Figure 4C) and VEGF protein secretion (Figure 4D) but that the specific ERK1/2 inhibitor PD98059 had no such effect (Figure 4E, 4F). These findings suggested that Dau inhibited IGF-I-induced HIF-1 $\alpha$ protein accumulation and VEGF expression mainly by PI-3K/Akt pathway but not through the ERK1/2 pathway.

mTOR, a downstream target gene of PI-3K/Akt, plays a crucial role in translation initiation ${ }^{[27,28]}$. The translational machinery has been shown to regulate HIF-1 $\alpha$ protein synthesis when it is induced by growth factor ${ }^{[8]}$. Therefore, we examined the effect of Dau on protein translational machinery. Our results showed that IGF-I stimulated 4E-BP1 and p70S6K phosphorylation (Figure 5A; lane $2 v$ lane 1) and that Dau blocked this effect (Figure 5A; lane 3-5). Moreover, the specific mTOR inhibitor rampamycin remarkably decreased IGF-I-induced HIF-1 $\alpha$ and VEGF protein expression levels (Figure 5B, 5C). Taken together, these results indicated that Dau could affect translational machinery and that Dau inhibited IGF-I-induced HIF-1 $\alpha$ protein accumulation and VEGF expression via the PI-3K/Akt /mTOR signaling pathway.

mTOR is activated under favorable growth conditions, leading to the phosphorylation of 4E-BP1 and p70S6K. The phosphorylation of 4E-BP1 can release eIF4E, initiating capdependent de novo translation of various species of mRNA. The phosphorylation of p70S6K triggers recruitment of the $40 \mathrm{~S}$ ribosome subunit and translation of 5'-terminal oli- gopyrimidine tract (5'TOP) mRNA that encodes the major components of protein synthesis apparatus ${ }^{[28]}$. Therefore, the inhibition of 4E-BP1 and p70S6K phosphorylation can suppress protein synthesis. In this study, we found Dau significantly inhibited 4E-BP1 and p70S6K phosphorylation at a concentration of $20 \mu \mathrm{mol} / \mathrm{L}$ (Figure 5A) and that HIF-1 $\alpha$ protein expression was completely blocked by rapamycin, which is a specific inhibitor of mTOR (Figure 5B). Therefore, Dau inhibited IGF-I-induced HIF- $1 \alpha$ protein expression probably by suppressing its protein synthesis.

HIF- $1 \alpha$ protein levels in the cells are regulated by a balance between its protein synthesis and degradation ${ }^{[8]}$. Studies by us and others have demonstrated that several natural products can affect both HIF- $1 \alpha$ protein synthesis and its degradation ${ }^{[8,29]}$. In this study, our results showed that Dau could inhibit HIF-1a protein synthesis by suppressing 4E-BP1 and p70S6K phosphorylation at a concentration of $20 \mu \mathrm{mol} / \mathrm{L}$ (Figure 5A). But $10 \mu \mathrm{mol} / \mathrm{L}$ Dau did not obviously decrease p-4E-BP1 levels (Figure 5A), and this significantly inhibited HIF- $1 \alpha$ protein accumulation (Figure $2 \mathrm{~A}$ ). Therefore, Dau may inhibit HIF-1 $\alpha$ protein accumulation by promoting its degradation in addition to suppressing its synthesis in response to IGF-I. To further validate this hypothesis, we next determined the half-life of HIF-1 $\alpha$ protein. Our results showed that the half-life of HIF-1 $\alpha$ protein was dramatically shortened in the presence of Dau at a concentration of $10 \mu \mathrm{mol} / \mathrm{L}$ (Figure 6), suggesting that Dau also promoted HIF-1 1 protein degradation in response to IGF-I.

In summary, in this study we have demonstrated that Dau inhibited IGF-I-induced HIF-1 1 p protein accumulation and VEGF expression in MCF-7 cells. The two main mechnisms by which this occurs are through blocking the activation of $\mathrm{PI}-3 \mathrm{~K} / \mathrm{Akt} / \mathrm{mTOR}$ signaling pathways and through the suppression of HIF-1 $\alpha$ protein synthesis as well as the promoting of its degradation. The data presented in this study suggest that Dau can inhibit human breast cancer angiogenesis by suppressing HIF-1 $\alpha$ protein accumulation and VEGF expression, which indicates that Dau may be a promising anti-angiogenic drug for human breast cancer.

\section{Acknowledgements}

This work was supported by the grants from the National Natural Science Foundation of China (№ 30872944), the Guangdong Administration of Traditional Chinese Medicine (No 2008166), and the Department of Science and Technology of Dongguan (№ 2008108101029).

We thank Prof Xiong-tai GUAN (Guangdong Medical College, Zhanjiang, China) for kindly providing Dau. We 
also thank Dr Anh D Le and Dr Qun-zhou ZHANG (Center for Craniofacial Molecular Biology, School of Dentistry, University of Southern California, Los Angeles, USA) for their technical assistance and strong support.

\section{Author contribution}

$\mathrm{Xu}$-dong TANG designed the project, performed the research, analyzed the data, and wrote the paper. Xin ZHOU designed the project and revised the paper. Ke-yuan ZHOU partly designed the project and revised the paper.

\section{References}

1 Yang XY, Jiang SQ, Zhang L, Liu QN, Gong PL. Inhibitory effect of dauricine on inflammatory process following focal cerebral ischemia/reperfusion in rats. Am J Chin Med 2007; 35: 477-86.

2 Su YM, Zhang C, Xiao JY, Gang HL, Wang ZG, Hua D. Effects of PAMD on the proliferation of human tumor cells of PC-3 and BT5637. Harbin Yi Ke Da Xue Xue Ba 2007; 41: 129-31. Chinese.

3 Al-Harris ES, Al-Janabi AA, Al-Toriahi KM, Yasseen AA. Over expression of vascular endothelial growth factor in correlation to Ki-67, grade, and stage of breast cancer. Saudi Med J 2008; 29: 1099-104.

4 Applanat MP, Buteau-Lozano H, Herve MA, Corpet A. Vascular endothelial growth factor is a target gene for estrogen receptor and contributes to breast cancer progression. Adv Exp Med Biol 2008; 617: 437-44.

5 Slomiany MG, Rosenzweig SA. Hypoxia-inducible factordependent and -independent regulation of insulin-like growth factor-1-stimulated vascular endothelial growth factor secretion. J Pharmacol Exp Ther 2006; 318: 666-75.

6 Catrina SB, Botusan IR, Rantanen A, Catrina AI, Pyakurel P, Savu $\mathrm{O}$, et al. Hypoxia-inducible factor-1alpha and hypoxia-inducible factor-2alpha are expressed in kaposi sarcoma and modulated by insulin-like growth factor-I. Clin Cancer Res 2006; 12: 4506-14.

7 Beppu K, Nakamura K, Linehan WM, Rapisarda A, Thiele CJ. Topotecan blocks hypoxia-inducible factor-1alpha and vascular endothelial growth factor expression induced by insulin-like growth factor-I in neuroblastoma cells. Cancer Res 2005; 65: 4775-81.

8 Cao Z, Fang J, Xia C, Shi X, Jiang BH. trans-3,4,5'-Trihydroxystibene inhibits hypoxia-inducible factor 1alpha and vascular endothelial growth factor expression in human ovarian cancer cells. Clin Cancer Res 2004; 10: 5253-63.

9 Kondo S, Seo SY, Yoshizaki T, Wakisaka N, Furukawa M, Joab I, et al. EBV latent membrane protein 1 up-regulates hypoxia-inducible factor 1alpha through Siah1-mediated down-regulation of prolyl hydroxylases 1 and 3 in nasopharyngeal epithelial cells. Cancer Res 2006; 66: 9870-7.

10 Tang X, Zhang Q, Nishitani J, Brown J, Shi SH, Le AD. Overexpression of human papillomavirus type 16 oncoproteins enhances hypoxia-inducible factor lalpha protein accumulation and vascular endothelial growth factor expression in human cervical carcinoma cells. Clin Cancer Res 2007; 13: 2568-76.

11 Zhang Q, Tang X, Zhang ZF, Velikina R, Shi S, Le AD. Nicotine induces hypoxia-inducible factor-1alpha expression in human lung cancer cells via nicotinic acetylcholine receptor-mediated signaling pathways. Clin Cancer Res 2007; 13: 4686- 94.

12 Vogelstein B, Kinzler KW. Cancer genes and the pathways they control. Nat Med 2004; 10: 789-99.

13 Gordan JD, Simon MC. Hypoxia-inducible factors: central regulators of the tumor phenotype. Curr Opin Genet Dev 2007; 17: 71-7.

14 Lopez-Lazaro M. Hypoxia-inducible factor 1 as a possible target for cancer chemoprevention. Cancer Epidemiol Biomarkers Prev 2006; 15: 2332-5.

15 Kimbro KS, Simons JW. Hypoxia-inducible factor-1 in human breast and prostate cancer. Endocr Relat Cancer 2006; 13: 73949.

16 Lin S, Tsai SC, Lee CC, Wang BW, Liou JY, Shyu KG. Berberine inhibits HIF-1alpha expression via enhanced proteolysis. Mol Pharmacol 2004; 66: 612-9.

17 Cai XF, Jin X, Lee D, Yang YT, Lee K, Hong YS, et al. Phenanthroquinolizidine alkaloids from the roots of boehmeria pannosa potently inhibit hypoxia-inducible factor-1 in AGS human gastric cancer cells. J Nat Prod 2006; 69: 1095-7.

18 Liu L, Ning X, Sun L, Shi Y, Han S, Guo C, et al. Involvement of MGr1-Ag/37LRP in the vincristine-induced HIF-1 expression in gastric cancer cells. Mol Cell Biochem 2007; 303: 151-60.

19 Chang TC, Huang CJ, Tam K, Chen SF, Tan KT, Tsai MS, et al. Stabilization of hypoxia-inducible factor-1alpha by prostacyclin under prolonged hypoxia via reducing reactive oxygen species level in endothelial cells. J Biol Chem 2005; 280: 36567-74.

20 Jung YJ, Isaacs JS, Lee S, Trepel J, Neckers L. IL-1beta-mediated up-regulation of HIF-1alpha via an NFkappaB/COX-2 pathway identifies HIF-1 as a critical link between inflammation and oncogenesis. FASEB J 2003; 17: 2115-7.

21 Zhang X, Kon T, Wang H, Li F, Huang Q, Rabbani ZN, et al. Enhancement of hypoxia-induced tumor cell death in vitro and radiation therapy in vivo by use of small interfering RNA targeted to hypoxia-inducible factor-1 $\alpha$. Cancer Res 2004; 64: 8139-42.

22 Slomiany MG, Black LA, Kibbey MM, Day TA, Rosenzweig SA. IGF-1 induced vascular endothelial growth factor secretion in head and neck squamous cell carcinoma. Biochem Biophys Res Commun 2006; 342: 851-8.

23 Fukuda R, Hirota K, Fan F, Jung YD, Ellis LM, Semenza GL. Insulin-like growth factor 1 induces hypoxia-inducible factor 1-mediated vascular endothelial growth factor expression, which is dependent on MAP kinase and phosphatidylinositol 3-kinase signaling in colon cancer cells. J Biol Chem 2002; 277: 38205-11.

24 Treins C, Giorgetti-Peraldi S, Murdaca J, Semenza GL, Van Obberghen E. Insulin stimulates hypoxia-inducible factor 1 through a phosphatidylinositol 3-kinase/target of rapamycindependent signaling pathway. J Biol Chem 2002; 277: 27975-81.

25 Munaron L, Tomatis C, Pla A. The Secret Marriage between calcium and tumor angiogenesis. Technol Cancer Res Treat 2008; 7: 335-40.

26 Khosravi Shahi P, Soria Lovelle A, Pérez Manga G. Tumoral angiogenesis and breast cancer. Clin Transl Oncol 2009; 11: 13842.

27 Gingras A, Raught B, Sonenberg N. Regulation of translation 
initiation by FRAP/mTOR. Genes Dev 2001; 15: 807-26.

28 Mita MM, Mita A, Rowinsky EK. Mammalian target of rapamycin: a new molecular target for breast cancer. Clin Breast Cancer 2003; 4: 126-37.

29 Zhang Q, Tang X, Lu Q, Zhang Z, Rao J, Le AD. Green tea extract and (-)-epigallocatechin-3-gallate inhibit hypoxia- and seruminduced HIF-1alpha protein accumulation and VEGF expression in human cervical carcinoma and hepatoma cells. Mol Cancer Ther 2006; 5: 1227-38.

30 Zhang Q, Tang X, Lu QY, Zhang ZF, Brown J, Le AD. Resveratrol inhibits hypoxia-induced accumulation of hypoxia-inducible factor-1alpha and VEGF expression in human tongue squamous cell carcinoma and hepatoma cells. Mol Cancer Ther 2005; 4: 1465-74. 